\title{
Climate Change Impact on Rice Yield in India - Vector Autoregression Approach
}

\author{
A. Jawahar Farook ${ }^{*}$ and K. Senthamarai Kannan \\ Department of Statistics, Manonmaniam Sundaranar University, \\ Tirunelveli-627012, Tamil Nadu, India. \\ *Corresponding Author: E-mail: farookstat@gmail.com and \\ senkannan2002@gmail.com
}

Received: 17, June 2014/ Revised: 26, September 2015/ Accepted: 09, October 2015

CIAppStat-SL2015

\begin{abstract}
Climate change plays an important role in agricultural production. Agricultural productivity is highly affected by a number of factors including precipitation, temperature. This paper examines the relationship between the yield of two major rice crops (e.g., Kharif and Rabi) and three main climate variables (e.g., maximum temperature, minimum temperature and rainfall). The dynamic relationships among the variables considered for observing the impact of climate change on rice yields are examined based on Vector Autoregression (VAR) model with the use of Granger causality test, impulse response functions and variance decomposition for the data. Maximum and Minimum temperature have significant effects, meanwhile rainfall has negative impact on Kharif rice yield. Adverse effects on Rabi rice yield are observed by maximum temperature and rainfall, whereas minimum temperature affect yield positively. Appropriate adaptive techniques are recommended to overcome this emerging hazard of climate change on rice production.
\end{abstract}

Keywords: VAR, Granger-causality test, impulse response function, variance decomposition, climate change, rice yield. 


\section{Introduction}

Intergovernmental Panel on Climate Change (IPCC) defines the climate change that the change in climate for the long period of time due to natural and anthropogenic activities. As a result of future increases in atmospheric concentration of greenhouse gases, it is predicted that the annual mean warming about $3^{\circ} \mathrm{C}$ in the decade of the 2050s and about $5^{\circ} \mathrm{C}$ in the decade of the 2080s over the land regions of Asia (IPCC, 2007). Increase in temperature and changes in precipitation have strong impacts on agriculture with the occurrence and strength of extreme weather events such as floods, droughts, cyclones and heat waves (IPCC, 2007). The vulnerability of climate change on agriculture could affect the food security, trade policy, livelihood activities, etc. It can affect the crop yield positively or negatively and the changes differ largely by region and crop. IPCC states that the developing countries will be more vulnerable to climate change than developed countries. India is considered one of most vulnerable countries, where the agricultural production is being affected by climate change.

IPCC has projected the temperature increase to be between $1.1^{\circ} \mathrm{C}$ and $6.4^{\circ} \mathrm{C}$ by the end of the $21^{\text {st }}$ century. Temperatures have been increasing in India especially during post monsoon and winter for the last few decades (IPCC, 2007). Rainfall is the most important variable and it has denoted an uneven distribution (Sarkar et al. ,2012). It is observed that the increase in extreme rains in north-west India during summer monsoon in recent decades and the number of rainy days in lower along east coast (IPCC, 2007). These unpredictable events produce floods and droughts which affects the crop yield (Adams et al., 1998). It is expected that an increase in mean annual temperature will be $3-6^{\circ} \mathrm{C}$ and rainfall will increase by $15-40 \%$ over India by the end of the $21^{\text {st }}$ century (National Communication Project, 2004).

Rice is the most important food crop of India. It covers about one third of total cultivated area of the country. About $23.3 \%$ of gross cropped area of the country is occupied with rice which accounts $43 \%$ of the total food grain production and $46 \%$ of the total cereal production of the country (Directorate of Rice Development, 2002). Given that approximately $15.7 \%$ of India's GDP is contributed by the agriculture sector and almost $60 \%$ of the country's population for its livelihood depends on this sector (Aggarwal et al., 2010). Rice production in India passed the amount of 100 million MT in 2011-2012 accounting for $22.81 \%$ of world production in that year.

Rice yield was noticed by International Rice Research Institute to decrease by $10 \%$ for every $1^{\circ} \mathrm{C}$ increase in growing-season minimum temperature (Peng et al., 2004). Lal et al. (1998) observed that a $4^{\circ} \mathrm{C}$ drop in surface air temperature results $10 \%$ 
reduction in rice yield, while a $4^{\circ} \mathrm{C}$ increase in temperature causes $41 \%$ reduction in rice yield. Sinha and Swaminathan (1991) observed that an increase of $2^{\circ} \mathrm{C}$ temperature could decrease the rice yield by about 0.75 ton/ha in the high yield areas. For every $1^{\circ} \mathrm{C}$ increase in temperature, it would decline the rice yield about 6\% (Saseendran et al., 2000). Therefore, it is essential need to appraise the possible influences of climate change on rice productivity to assure food security and economic growth.

The influences of climate change on agriculture have been studied on developing countries earlier (Lansigan et al., 2000; Chang, 2002; Gbetibouo and Hassan, 2005;Kurukulasuriya and Ajwad, 2007; Kabubo-Mariara and Karanja, 2007; Haim et al., 2008; Sanghi and Mendelsohn, 2008; Deressa and Hassan, 2009; Moula, 2009; and Wang et al., 2009). From those studies, it is revealed that the crop yield is more prone to climate change in developing countries. Though the agricultural status of India is most vulnerable to climate change, there are limited empirical investigations of the impact of climate change on crop agriculture ( Lal et al., 1998; Auffhammer et al., 2011; Krishna Kumar et al., 2004; and Aggarwal et al., 2010).

Aggarwal et al. (2010) identified that rice and wheat crops are likely to be affected by the climate change. They have done the simulation analysis using InfoCropWheat and InfoCrop-Rice models in the study area comprising 11 districts in northwest Uttar Pradesh and south-west Uttarakhand. Lal et al. (1998) discussed the vulnerability of wheat and rice crops in north-west India by adopting CERES v3. models (crop growth simulation models for wheat and rice). They also revealed that the wheat and rice productivity could be adversely affected by acute water shortage conditions combined with the thermal stress than increased $\mathrm{CO}_{2}$ concentration in general.

Auffhammer et al. (2011) showed that rice yield is affected by the droughts and extreme rainfall in rain-fed areas during 1966-2002 by applying multiple regression. Simulation study that uses the regression based estimates to identify the impacts of changes in monsoon characteristics on rice yield has been also undertaken. Krishna Kumar et al. (2004) presented a correlation analysis to identify the crop-climate relationships for India. They showed the significant relationship of rainfall and some of its potential predictors on crop production. The time series data on both climate variables and yields is employed by regression models, which are proficient to assess accurate estimates of the changes in crop yield as a result of changes in climate variables (Almaraz et al., 2008; Lobell and Field, 2007; Joshi et al., 2011; and Isik and Devadoss, 2006). 
Climate variables such as temperature, precipitation and solar radiation are generally considered to study the climate change and its impact. Peng et al. (2004) identified the direct correlation between temperature and solar radiation. To conquer the relationship among the independent variables, this paper considers only temperature and precipitation. Minimum temperature, maximum temperature and rainfall are the three climate variables used as independent variables by considering Almaraz et al. (2008).

There are two major rice crops, Kharif and Rabi, which constitute $100 \%$ of total rice production and grow in two different seasons in India. The sowing time of Kharif rice is June or July and it is harvested in November or December. Rabi is sown in November to February and harvested in March to June. However, the sowing and harvesting time slightly vary from state to state according to weather condition and rainfall pattern. In this study, the growing seasons are considered as June to December for Kharif and January-May for Rabi. In the view of the fact that the average growing season climate is able to show the net effects of climate change on crop yields (Lobell and Field, 2007), this study has used an average growing season temperature variable with the total growing season rainfall variable.

Consequently, it is necessary for identifying the relationship between climate variables and crop yields through empirical studies. There are several studies conducted on an international level to study the influence of climate variables on crop production but not on rice yield (Almaraz et al., 2008; Ozcan and Akcaoz, 2002). The stationary properties of the time series data have not been determined in those studies. It is a precondition for performing the time series for a period of more than 20 years (Chen et al., 2004). The main objective of this article is to examine the relationships between three climate variables and rice yields of Kharif and Rabi in India.

\section{Data Sources and Properties}

The monthly maximum temperature, minimum temperature and total rainfall data for months January through to December for the period 1974-2011 were obtained from the Indian Meteorological Department (IMD). These monthly data were then transformed as the average of the growing periods for two rice crops: Kharif (JuneDecember) and Rabi (January-May). Therefore, maximum and minimum average temperature and total rainfall are considered as the climate variables for the growing seasons of the respective rice crops for the 1974-2011 periods. Aggregate rice yield data for Kharif and Rabi for the same time period (1974-2011) were collected from Directorate of Rice Development, Patna. 
The basic statistics for all of the data are presented in Table 1. The mean value for the Rabi rice yield is higher than the Kharif rice. The highest mean maximum and minimum temperatures are observed for the Kharif rice, while the lowest temperatures were observed for the Rabi rice. In contrast, total rainfall in the Kharif period is approximately eight times higher than the total rainfall in the Rabi period.

Table 1: Descriptive statistics for the data for 1974-2011 period

\begin{tabular}{|c|c|c|c|c|c|c|c|c|}
\hline \multirow{3}{*}{ Statistics } & \multicolumn{8}{|c|}{ Variables } \\
\hline & \multicolumn{2}{|c|}{$\begin{array}{l}\text { Yield (kg per } \\
\text { Hectare) }\end{array}$} & \multicolumn{2}{|c|}{$\begin{array}{c}\text { Maximum } \\
\text { Temperature } \\
\left({ }^{\circ} \mathrm{C}\right)\end{array}$} & \multicolumn{2}{|c|}{$\begin{array}{c}\text { Minimum } \\
\text { Temperature } \\
\left({ }^{\circ} \mathrm{C}\right)\end{array}$} & \multicolumn{2}{|c|}{$\begin{array}{c}\text { Rainfall } \\
(\mathbf{m m})\end{array}$} \\
\hline & Kharif & Rabi & Kharif & Rabi & Kharif & Rabi & Kharif & Rabi \\
\hline Mean & 1646.76 & 2620.82 & 29.56 & 28.51 & 20 & 17.33 & 9550.11 & 1191.55 \\
\hline Std.dev & 342.31 & 427.10 & 0.30 & 0.55 & 0.36 & 0.49 & 848.32 & 230.64 \\
\hline Maximum & 2284 & 3275 & 30.27 & 29.76 & 21 & 18.30 & 11119 & 1920 \\
\hline Minimum & 999 & 1888 & 28.82 & 27.65 & 19.04 & 16.50 & 7557 & 767 \\
\hline Skewness & -0.25 & -0.31 & 0.35 & 0.61 & -0.04 & 0.28 & -0.25 & 0.65 \\
\hline Kurtosis & -0.92 & -1.27 & 0.25 & -0.35 & 1.46 & -0.69 & -0.56 & 1.47 \\
\hline
\end{tabular}

\section{Methodology}

This study can be employed by the Vector Autoregression modeling to identify the causal relationships between climate variables and rice yield to estimate the possible effects of climate change. VAR models were first developed by Sims (1980) as a better alternative to traditional dynamic simultaneous equation models to examine the dynamic interactions among the interrelated time series data. VAR models are the multivariate extensions of the univariate AR models to the multivariate case and they explain and/or predict the values of a set of variables at any given point in time (Sims, 1980; and Todd, 1984). They are extensively used in forecasting and causality tests (Cooley and Leroy, 1985).

The basic $p$-lag vector auto-regression model has the form

$$
\mathrm{Y}_{\mathrm{t}}=\mathrm{c}+\Gamma_{1} \mathrm{Y}_{\mathrm{t}-1}+\Gamma_{2} \mathrm{Y}_{\mathrm{t}-2}+\ldots+\Gamma_{\mathrm{p}} \mathrm{Y}_{\mathrm{t}-\mathrm{p}}+\varepsilon_{\mathrm{t}}, \quad \mathrm{t}=1, \ldots, \mathrm{T}
$$

where $Y_{t}=\left(y_{1 t}, y_{2 t}, \ldots y_{n t}\right)^{\prime}$ denote an $(n x 1)$ vector of time series variables

$\Gamma_{\mathrm{i}}$ are (nxn) coefficient matrices and 
$\varepsilon_{\mathrm{t}}$ is an (nx1) unobservable zero mean white noise vector process (serially uncorrelated or independent) with time invariant covariance matrix $\Sigma$.

For example, a bivariate VAR model is defined by

$$
\left(\begin{array}{l}
\mathrm{y}_{1 \mathrm{t}} \\
\mathrm{y}_{2 \mathrm{t}}
\end{array}\right)=\left(\begin{array}{l}
\mathrm{c}_{1} \\
\mathrm{c}_{2}
\end{array}\right)+\left(\begin{array}{ll}
\Gamma_{11}^{1} & \Gamma_{12}^{1} \\
\Gamma_{21}^{1} & \Gamma_{22}^{1}
\end{array}\right)\left(\begin{array}{l}
\mathrm{y}_{1 \mathrm{t}-1} \\
\mathrm{y}_{2 \mathrm{t}-1}
\end{array}\right)+\left(\begin{array}{cc}
\Gamma_{11}^{2} & \Gamma_{12}^{2} \\
\Gamma_{21}^{2} & \Gamma_{22}^{2}
\end{array}\right)\left(\begin{array}{l}
\mathrm{y}_{1 \mathrm{t}-2} \\
\mathrm{y}_{2 \mathrm{t}-2}
\end{array}\right)+\left(\begin{array}{c}
\varepsilon_{1 \mathrm{t}} \\
\varepsilon_{2 \mathrm{t}}
\end{array}\right)
$$

where $\operatorname{cov}\left(\varepsilon_{1 \mathrm{t}}, \varepsilon_{2 \mathrm{~s}}\right)=\left\{\begin{array}{cc}\sigma_{12}, & \mathrm{t}=\mathrm{s} \\ 0, & \text { otherwise }\end{array}\right.$

In lag operator notation, the $\operatorname{VAR}(p)$ is written as

$$
\Gamma(\mathrm{B}) \mathrm{Y}_{\mathrm{t}}=\mathrm{c}+\varepsilon_{\mathrm{t}}, \text { where } \Gamma(\mathrm{B})=\mathrm{I}_{\mathrm{n}}-\Gamma_{1} \mathrm{~B}-\ldots-\Gamma_{\mathrm{p}} \mathrm{B}^{\mathrm{p}}
$$

All variables are served as endogenous variables, each equation has the same exogenous variables and the lagged exogenous variables. In other words, each endogenous variable is explained by its lagged or past values and the lagged values of all other endogenous variables in the model. An important preliminary step in model building is the selection of the VAR lag order. One way of determining the optimum lag order is to use the minimum information criterion such as Akaike Information, Schwarz criterion or Hannan-Quinn information criterion.

The estimation of the parameters of the VAR model is not difficult, though the structure of the VAR model looks very complex. They can be easily estimated by Ordinary Least Square (OLS) method or Maximum Likelihoods.

\subsection{Granger causality test}

The supplementary advantage of VAR model is to perform the Granger causality testing to examine the direction of causality among the variables (Granger, 1969). It is a technique for determining whether one time series is useful in forecasting another. If a variable say, $X$ is found to be helpful for predicting another variable say, $Y$, then $X$ is said to Granger-cause $Y$. To test the null hypothesis that $X$ does not Granger-cause $Y$, the test statistic is given by

$$
\mathrm{F}=\frac{\left(\mathrm{RSS}_{\mathrm{R}}-\mathrm{RSS}_{\mathrm{UR}}\right) / \mathrm{m}}{\mathrm{RSS}_{\mathrm{UR}} /(\mathrm{n}-\mathrm{k})}
$$

where $R S S_{R}$, restricted residual sum of squares, $R S S_{U R}$, unrestricted residual sum of squares, $m$, number of lagged $\mathrm{X}$ terms, and $k$, number of parameters estimated in the unrestricted regression. 
The test statistic follows the F-distribution with $m$ and $(n-k)$ degrees of freedom.

\subsection{Impulse Response Functions and Variance Decompositions}

Impulse response functions provided by VAR models are used to know where the impact of change in one variable can be found through all the other variables. They exhibit the current and lagged effects over time of changes in error terms $\left(\varepsilon_{1 \mathrm{t}}, \varepsilon_{2 \mathrm{t}}, \ldots, \varepsilon_{\mathrm{kt}}\right)$ on the endogenous variables $\left(\mathrm{y}_{1 \mathrm{t}}, \mathrm{y}_{2 \mathrm{t}}, \ldots, \mathrm{y}_{\mathrm{kt}}\right)$. When the VAR process of order ' $p$ ' is stable, the error term $\varepsilon_{1 \mathrm{t}}$ has immediate effects and $\varepsilon_{2 \mathrm{t}}, \varepsilon_{3 \mathrm{t}}, \ldots, \varepsilon_{\mathrm{kt}}$ all have lagged effects on $y_{1 t}$.

If any covariance stationary $\operatorname{VAR}(p)$ process has a Wald representation of the form

$$
Y_{t}=\mu+\varepsilon_{t}+\phi_{1} \varepsilon_{t-1}+\phi_{2} \varepsilon_{t-2}+\ldots
$$

where $\phi_{s}$ are (nxn) moving average matrices, the impulse responses, $\varphi_{i j}^{s},(\mathrm{i}, \mathrm{j})^{\text {th }}$ element of $\phi_{s}$ are defined by

$$
\frac{\partial \mathrm{y}_{\mathrm{i}, \mathrm{t}+\mathrm{s}}}{\partial \varepsilon_{\mathrm{j}, \mathrm{t}}}=\frac{\partial \mathrm{y}_{\mathrm{i}, \mathrm{t}}}{\partial \varepsilon_{\mathrm{j}, \mathrm{t}-\mathrm{s}}}=\varphi_{\mathrm{ij}}^{\mathrm{s}}, \quad \mathrm{i}, \mathrm{j}=1,2, \ldots, \mathrm{n}
$$

It is only possible if $\operatorname{var}\left(\varepsilon_{\mathrm{t}}\right)=\Sigma$ is a diagonal matrix in which $\varepsilon_{t}$ are uncorrelated.

The variance decomposition analysis is typically performed by VAR models, which supplements impulse response function analysis (Ghatak, 1998). It shows that how much the variance of the forecast errors of each variable can be explained by exogenous shocks to the other variables in the VAR.

\section{Results and Discussions}

As the data set contains more than 20 years of observations, it requires testing of the unit roots for examining stationary of the series (Chen et al., 2004). Augmented Dickey Fuller (ADF) test is incorporated here and the results are presented in Table 2. Table 2 shows that the yields, maximum and minimum temperature for Kharif and Rabi rice are integrated of order one. 
Table 2: Results of Augmented Dickey Fuller (ADF) test for determining the stationarity of the time series

\begin{tabular}{|l|c|c|c|c|c|c|}
\hline \multirow{2}{*}{ Variables } & \multicolumn{3}{|c|}{ Kharif } & \multicolumn{3}{c|}{ Rabi } \\
\cline { 2 - 7 } & $\begin{array}{c}\text { ADF test } \\
\text { statistic }\end{array}$ & p-value & $\begin{array}{c}\text { Integration } \\
\text { of order }\end{array}$ & $\begin{array}{c}\text { ADF test } \\
\text { statistic }\end{array}$ & p-value & $\begin{array}{c}\text { Integration } \\
\text { of order }\end{array}$ \\
\hline Yield & -7.7342 & $2.96 \mathrm{e}-12$ & $\mathrm{I}(1)$ & -7.1416 & $1.36 \mathrm{e}-10$ & $\mathrm{I}(1)$ \\
Max.Temperature & -6.7780 & $1.3 \mathrm{e}-09$ & $\mathrm{I}(1)$ & -8.2704 & $7.93 \mathrm{e}-14$ & $\mathrm{I}(1)$ \\
Min.Temperature & -7.1951 & $9.73 \mathrm{e}-11$ & $\mathrm{I}(1)$ & -8.4105 & $3.02 \mathrm{e}-14$ & $\mathrm{I}(1)$ \\
Total rainfall & -3.8940 & 0.0021 & $\mathrm{I}(0)$ & -4.9202 & $2.97 \mathrm{e}-05$ & $\mathrm{I}(0)$ \\
\hline
\end{tabular}

However, the total rainfall for Kharif and Rabi rice are of $\mathrm{I}(0)$, which indicates those data series are stationary in their level form. The variables with I(1) mean that they generally become stationary only after taking their first differences before estimation (Gujarati et al., 2009).

Table 3: Values of the Information Criterion for selecting the order of the VAR model for Kharif and Rabi rice

\begin{tabular}{|c|c|c|c|c|c|c|}
\hline \multirow{2}{*}{ Lag } & \multicolumn{3}{|c|}{ Kharif } & \multicolumn{3}{c|}{ Rabi } \\
\cline { 2 - 7 } & AIC & BIC & HQC & AIC & BIC & HQC \\
\hline 1 & $28.1632^{*}$ & $29.1953^{*}$ & $28.6133^{*}$ & $28.4467^{*}$ & $29.3355^{*}$ & $28.7535^{*}$ \\
2 & 28.1781 & 29.7630 & 28.7154 & 28.6787 & 30.2785 & 29.2310 \\
3 & 28.3065 & 30.4889 & 28.9758 & 28.5546 & 30.8654 & 29.3523 \\
\hline
\end{tabular}

Table 3 gives the values of different information criterion for the various lag length of the VAR models to the Kharif and Rabi rice. From the results, the optimal lag order is one for both rice with the values of minimum AIC, BIC and HQC.

\subsection{The Results for the Kharif rice}

For the Kharif rice, the following VAR(1) model is employed by considering rice yield and climate variables

$$
\text { yield }_{t}=\alpha_{0}+\alpha_{1} \text { yield }_{t-1}+\alpha_{2} \operatorname{maxt}_{t-1}+\alpha_{3} \operatorname{mint}_{t-1}+\alpha_{4} \operatorname{train}_{t-1}+\varepsilon_{1 t}
$$

where yield is the Kharif rice yield (in $\mathrm{kg}$ per hectare), maxt is the average maximum temperature $\left({ }^{\circ} \mathrm{C}\right)$ from June to December, mint is the average minimum temperature $\left({ }^{\circ} \mathrm{C}\right)$ from June to December, train is the total rainfall (mm) from June to December, $\varepsilon_{1 \mathrm{t}}$ is the error term and $t$ is the time (i.e., year).

From Table 4, the effects of the climate variables on the Kharif rice yield is obtained that the overall model is statistically significant. The $R^{2}$ value indicates that 
$88 \%$ of the variation in the Kharif rice is explained by climate variables. The higher value of F-statistic (59.19) makes collectively all the lagged terms are statistically significant. Granger causality test results from Table 5 suggest that the direction of causality is from maxt and mint to yield since the F-statistic is significant. But there is no causation from train to yield, since the F value is statistically insignificant.

As shown from Figure 1(a) about impulse response functions for a period of 10 years from maxt and mint to yield, increasing of maxt and mint in the current period has a positive effect on yield in the future and from third period it shows a decreasing trend of positive effect until ninth period. According to the Figure 1(a) about impulse response functions from train to yield, increasing of train in the current period has a negative effect on yield. It has positive effect during second period but after third period, it begins to a slow decline.

Table 6 gives the variance decomposition values of rice yield for both categories. During the changes of yield, its own affect is $100 \%$ in first period and then gradually declines to $67.42 \%$. The volatility of yield from $0 \%$ to $19.72 \%$ fluctuations can be explained by maxt; $0 \% \sim 0.37 \%$ and $0 \% \sim 12.49 \%$ fluctuations can be explained by mint and train respectively. All the above results imply a higher contribution of maximum temperature and minimum temperature to the Kharif rice yield. Although total rainfall during Kharif period is insignificant, it is negatively associated with the rice yield.

\subsection{The results for the Rabi rice}

On the basis of the distribution of the Rabi rice yield, the following VAR model of order one is used.

$$
\text { yield }_{\mathrm{t}}=\beta_{0}+\beta_{1} \text { yield }_{\mathrm{t}-1}+\beta_{2} \operatorname{maxt}_{\mathrm{t}-1}+\beta_{3} \text { mint }_{\mathrm{t}-1}+\beta_{4} \operatorname{train}_{\mathrm{t}-1}+\varepsilon_{2 \mathrm{t}}
$$

where yield is the Rabi rice yield (in kg per hectare), maxt is the average maximum temperature $\left({ }^{\circ} \mathrm{C}\right)$ from January to May, mint is the average minimum temperature $\left({ }^{\circ} \mathrm{C}\right)$ from January to May, train is the total rainfall $(\mathrm{mm})$ from January to May, $\varepsilon_{2 t}$ is the error term and $t$ is the time (i.e., year). 
Table 4: The Estimated Vector Autoregression models of Kharif and Rabi rice

\begin{tabular}{|c|c|c|c|c|c|c|c|c|}
\hline \multicolumn{9}{|c|}{$\begin{array}{l}\text { Vector autoregression estimates based on } 1 \text { lag } \\
\text { Sample (adjusted): } 1974-2011 \\
\text { Included observations: } 37 \text { after adjustments } \\
\text { Standard errors in ( ) and } t \text {-statistics in [ ] }\end{array}$} \\
\hline & \multicolumn{4}{|c|}{ Kharif } & \multicolumn{4}{|c|}{ Rabi } \\
\hline & yield & maxt & mint & train & yield & maxt & mint & train \\
\hline yield $(-1)$ & $\begin{array}{c}0.865585 \\
(0.07503) \\
{[11.54]}\end{array}$ & $\begin{array}{c}0.00045 \\
(0.00016) \\
{[2.7630]}\end{array}$ & $\begin{array}{c}0.00051 \\
(0.00018) \\
{[2.795]}\end{array}$ & $\begin{array}{l}-0.51266 \\
(0.53429) \\
{[-0.9595]}\end{array}$ & $\begin{array}{c}0.85061 \\
(0.09225) \\
{[9.220]}\end{array}$ & $\begin{array}{c}0.00075 \\
(0.00024) \\
{[3.076]}\end{array}$ & $\begin{array}{c}0.00063 \\
(0.00021) \\
{[2.925]}\end{array}$ & $\begin{array}{c}0.22587 \\
(0.12637) \\
{[1.787]}\end{array}$ \\
\hline $\operatorname{maxt}(-1)$ & $\begin{array}{c}15.7418 \\
(123.849) \\
{[0.1271]}\end{array}$ & $\begin{array}{c}0.12698 \\
(0.27063) \\
{[0.4692]}\end{array}$ & $\begin{array}{l}-0.08049 \\
(0.30405) \\
{[-0.2647]}\end{array}$ & $\begin{array}{c}-821.088 \\
(881.0881) \\
{[-0.9311]}\end{array}$ & $\begin{array}{c}-6.80272 \\
(109.684) \\
{[-0.06202]}\end{array}$ & $\begin{array}{l}-0.04122 \\
(0.29052) \\
{[-0.1419]}\end{array}$ & $\begin{array}{c}-0.16232 \\
(0.25541) \\
{[-0.6355]}\end{array}$ & $\begin{array}{c}-68.0752 \\
(150.250) \\
{[-0.4531]}\end{array}$ \\
\hline $\operatorname{mint}(-1)$ & $\begin{array}{c}99.4669 \\
(90.7924) \\
{[1.096]}\end{array}$ & $\begin{array}{l}0.00184 \\
(0.19840) \\
{[0.00929]}\end{array}$ & $\begin{array}{c}0.16652 \\
(0.22290) \\
{[0.7471]}\end{array}$ & $\begin{array}{c}625.770 \\
(646.496) \\
{[0.9695]}\end{array}$ & $\begin{array}{c}121.960 \\
(127.243) \\
{[0.9585]}\end{array}$ & $\begin{array}{c}0.18136 \\
(0.33702) \\
{[0.5381]}\end{array}$ & $\begin{array}{c}0.26450 \\
(0.29630) \\
{[0.8927]}\end{array}$ & $\begin{array}{l}-29.3737 \\
(174.302) \\
{[-0.1685]}\end{array}$ \\
\hline train (-1) & $\begin{array}{c}-0.08160 \\
(0.03010) \\
{[-2.711]}\end{array}$ & $\begin{array}{c}0.00002 \\
(0.00007) \\
{[0.3374]}\end{array}$ & $\begin{array}{c}0.00003 \\
(0.00007) \\
{[0.4148]}\end{array}$ & $\begin{array}{c}-0.21743 \\
(0.21436) \\
{[-1.014]}\end{array}$ & $\begin{array}{c}-0.35644 \\
(0.13538) \\
{[-2.633]}\end{array}$ & $\begin{array}{l}-0.00022 \\
(0.00036) \\
{[-0.6034]}\end{array}$ & $\begin{array}{c}0.00003 \\
(0.00032) \\
{[0.1008]}\end{array}$ & $\begin{array}{l}-0.11854 \\
(0.18545) \\
{[-0.6392]}\end{array}$ \\
\hline constant & $\begin{array}{l}-1420.48 \\
(2872.40) \\
{[-0.4945]} \\
\end{array}$ & $\begin{array}{c}24.8329 \\
(6.27664) \\
{[3.956]} \\
\end{array}$ & $\begin{array}{c}17.9376 \\
(7.05181) \\
{[2.544]} \\
\end{array}$ & $\begin{array}{c}24224.6 \\
(20453.2) \\
{[1.184]} \\
\end{array}$ & $\begin{array}{l}-1068.01 \\
(1806.24) \\
{[-0.5913]} \\
\end{array}$ & $\begin{array}{c}24.8573 \\
(4.78415) \\
{[5.196]} \\
\end{array}$ & $\begin{array}{c}15.7200 \\
(4.20595) \\
{[3.738]} \\
\end{array}$ & $\begin{array}{c}3199.69 \\
(2474.27) \\
{[1.293]} \\
\end{array}$ \\
\hline R-squared & 0.88094 & 0.32165 & 0.33966 & 0.08966 & 0.84908 & 0.40570 & 0.39215 & 0.09408 \\
\hline Adj. R-squared & 0.86605 & 0.23685 & 0.25712 & -0.02414 & 0.83022 & 0.33141 & 0.31617 & 0.01916 \\
\hline Sum squared residuals & 464902 & 2.21986 & 2.80202 & 23571874 & 936287.2 & 6.56848 & 5.07672 & 1756908 \\
\hline S.E of regression & 120.5329 & 0.26339 & 0.29591 & 858.2663 & 171.0525 & 0.45306 & 0.39831 & 234.3147 \\
\hline F-statistic & 59.19055 & 3.79323 & 4.11498 & 0.78791 & 45.00816 & 5.46121 & 5.16116 & 0.83084 \\
\hline p-value & $2.46 \mathrm{e}-14$ & 0.01236 & 0.00841 & 0.54161 & $1.06 \mathrm{e}-12$ & 0.00181 & 0.00253 & 0.51556 \\
\hline Mean dependent & 1664.270 & 29.57270 & 20.01881 & 9572.946 & 2640.514 & 28.52385 & 17.35129 & 1196.081 \\
\hline S.D. dependent & 329.3355 & 0.301497 & 0.34332 & 848.0930 & 415.1257 & 0.55409 & 0.48166 & 232.1022 \\
\hline Durbin-Watson & 2.35829 & 2.03892 & 2.31300 & 1.81426 & 2.74018 & 1.95711 & 2.01075 & 1.91826 \\
\hline Log likelihood & \multicolumn{4}{|c|}{-503.57919} & \multicolumn{4}{|c|}{$\begin{array}{l}-505.22514 \\
\end{array}$} \\
\hline Determinant of cov. matrix & \multicolumn{4}{|c|}{7794964.5} & \multicolumn{4}{|c|}{8520272.4} \\
\hline AIC & \multicolumn{4}{|c|}{28.3016} & \multicolumn{4}{|c|}{28.3905} \\
\hline BIC & \multicolumn{4}{|c|}{29.1723} & \multicolumn{4}{|c|}{29.2613} \\
\hline HQC & \multicolumn{4}{|c|}{28.6086} & \multicolumn{4}{|c|}{28.6975} \\
\hline
\end{tabular}


Table 5: Results of Granger causality test

\begin{tabular}{|c|c|c|c|c|c|c|}
\hline \multirow{2}{*}{ Null Hypothesis } & \multicolumn{3}{|c|}{ Kharif } & \multicolumn{3}{c|}{ Rabi } \\
\cline { 2 - 7 } & F-statistic & p-value & conclusion & F-statistic & p-value & conclusion \\
\hline $\begin{array}{c}\text { maxt does not } \\
\text { Granger-cause yield }\end{array}$ & 7.6357 & 0.0094 & Reject & 9.4601 & 0.0043 & Reject \\
$\begin{array}{c}\text { mint does not } \\
\text { Granger-cause yield }\end{array}$ & 7.8122 & 0.0087 & Reject & 8.5540 & 0.0063 & Reject \\
$\begin{array}{c}\text { train does not } \\
\text { Granger-cause yield }\end{array}$ & 0.92066 & 0.3445 & Do not reject & 3.1947 & 0.0834 & Reject $^{*}$ \\
\hline
\end{tabular}

* Reject at $10 \%$ level of significance

The contribution of climate variables to the Rabi rice is presented in Table 4. It is observed that the F-statistic value associated with p-value ensures the significance of the model. Moreover, $85 \%$ of the variation in Rabi rice yield is explained by the climate variables, which represents the important role of climate for Rabi rice cultivation.

The results from Table 5 indicate that there is causal relationship between climate variables and Rabi rice yield. The null hypothesis in each case assumes that maxt, mint and train does not 'Granger-cause' the yield. Since the F-statistic is statistically significant, the direction of causality from maxt, mint and train to yield is observed. It is necessary to observe that the impulse response functions of maxt, mint and train to Rabi rice yield. Figure 1(b) traces out the responses of maxt, mint and train. According to the figure about impulse response functions from climate variables to yield, increasing of maxt, mint and train in the current period has a positive effect on yield in the future and shows a decreasing trend of positive effect until the tenth period. 
A. Jawahar Farook and K. Senthamarai Kannan
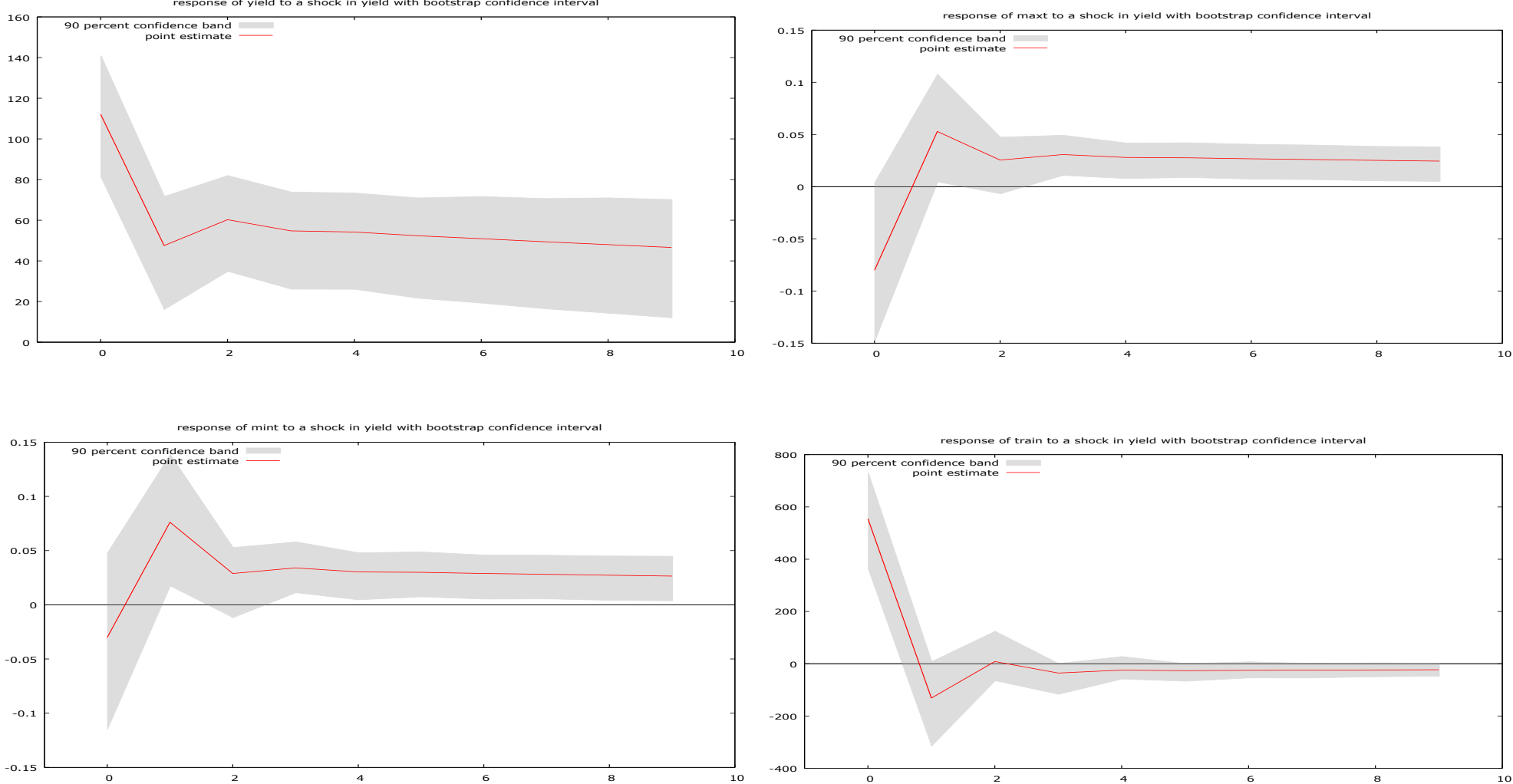

a) Responses of yield, maxt, mint and train to Kharif rice yield 

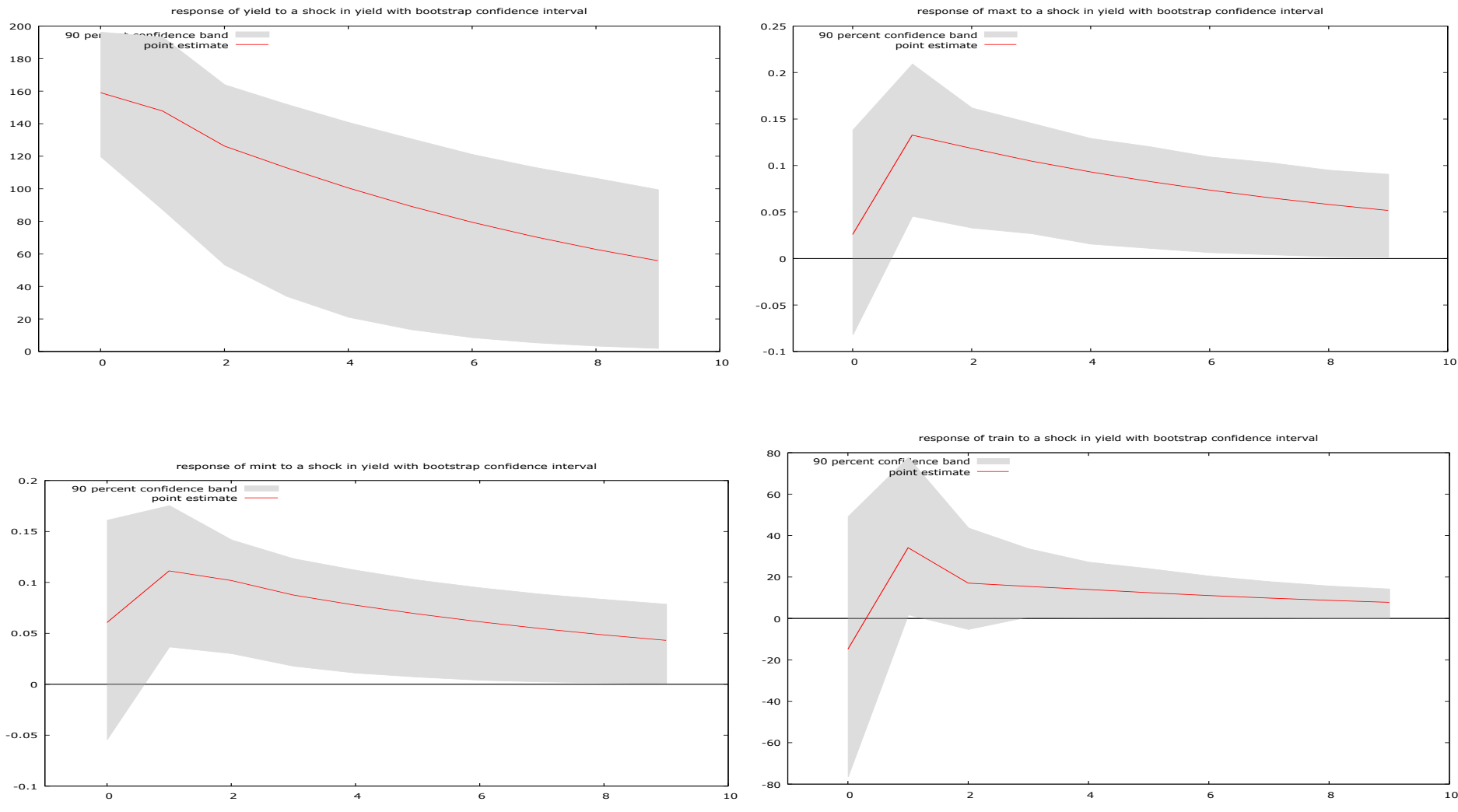

b) Responses of yield, maxt, mint and train to Rabi rice yield

Figure 1: Impulse Response Functions of climate variables on rice yield 
Table 6: Forecast Error Variance Decompositions for rice yield

\begin{tabular}{|c|c|c|c|c|c|c|c|c|c|c|}
\hline \multirow{2}{*}{$\begin{array}{c}\text { Perio } \\
\text { d }\end{array}$} & \multicolumn{9}{|c|}{ Kharif } & \multicolumn{3}{|c|}{ Rabi } \\
\cline { 2 - 11 } & S.E & yield & maxt & mint & train & S.E & yield & maxt & mint & train \\
\hline 1 & 112.09 & 100.00 & 0.00 & 0.00 & 0.00 & 159.08 & 100.00 & 0.00 & 0.00 & 0.00 \\
2 & 134.57 & 81.86 & 8.26 & 0.40 & 9.48 & 232.68 & 87.10 & 3.86 & 0.02 & 9.02 \\
3 & 154.12 & 77.70 & 12.06 & 0.35 & 9.89 & 274.42 & 83.78 & 6.25 & 0.16 & 9.81 \\
4 & 170.01 & 74.23 & 14.54 & 0.36 & 10.86 & 302.97 & 82.63 & 7.05 & 0.25 & 10.07 \\
5 & 183.84 & 72.17 & 16.14 & 0.36 & 11.34 & 323.75 & 82.00 & 7.47 & 0.30 & 10.22 \\
6 & 195.97 & 70.65 & 17.28 & 0.36 & 11.71 & 339.28 & 81.60 & 7.75 & 0.33 & 10.32 \\
7 & 206.76 & 69.53 & 18.12 & 0.36 & 11.98 & 351.07 & 81.33 & 7.93 & 0.36 & 10.38 \\
8 & 216.44 & 68.67 & 18.78 & 0.36 & 12.19 & 360.11 & 81.14 & 8.05 & 0.37 & 10.43 \\
9 & 225.18 & 67.98 & 19.30 & 0.37 & 12.36 & 367.10 & 81.00 & 8.15 & 0.38 & 10.46 \\
10 & 233.13 & 67.42 & 19.72 & 0.37 & 12.49 & 372.53 & 80.91 & 8.22 & 0.39 & 10.49 \\
\hline
\end{tabular}

From variance decomposition values of Rabi rice yield which are shown in Table 6, $100 \% \sim 80.91 \%$ fluctuations can be explained by their own yield fluctuations; $0 \% \sim 8.22 \%, 0 \% \sim 0.39 \%$ and $0 \% \sim 10.49 \%$ fluctuations can be explained by the volatility of maxt, mint and train respectively. The above results show that all the climate variables are statistically significant for Rabi rice yield. However, the effects of maximum temperature and total rainfall are negative, whereas minimum temperature has a positive influence on Rabi rice yield.

\section{Conclusions}

This paper analyzed the impact of climate change on rice yield using aggregatelevel time series data. Three climate variables have significant effects on the rice yield of Kharif and Rabi crops. For the Kharif rice yield, average maximum temperature and average minimum temperature are statistically significant. Moreover, total rainfall is perceived to adversely affect the Kharif rice yield, despite this effect is not significant. For the Rabi rice yield, all three climate variables were statistically significant. However, the direction of the effects is not identical. Average maximum temperature and total rainfall have negative effects on yield, whereas average minimum temperature affect yield positively. Given these influences of climate factors on the rice yield, it is recommended the adaptive techniques to overcome this situation.

\section{Acknowledgement}

The first author express his gratitude to the DST for providing fellowship to carry out this work under the scheme of Innovation in Science Pursuit for Inspired Research (INSPIRE) program. The second author acknowledges University Grant Commission for providing the infrastructure facility under SAP (DRS-I) to carry out this work. 


\section{References}

1. Adams, R.M., Hurd, B.H., Lenhart, S., and Leary, N. (1998). Effects of Global Climate Change on Agriculture: An Interpretative Review, Climate Research, 11, 19-30. DOI: 10.3354/cr011019

2. Aggarwal, P.K., Kumar, S.N., and Pathak, H. (2010). Impacts of Climate Change on Growth and Yield of Rice and Wheat in the Upper Ganga Basin. WWF-India Report.

3. Almaraz, J.J., Mabood, F., Zhou, X., Gregorich, E.G., and Smith, D.L. (2008). Climate Change, Weather Variability and Corn Yield at a Higher Latitude Locale: Southwestern Quebec, Climatic Change, 88, 187-197. DOI: 10.1007/s10584-008-9408-y

4. Auffhammer, M., Ramanathan, V., and Vincent, J.R. (2011). Climate Change, the Monsoon, and Rice Yield in India, Climatic Change, 111(2), 411-424. DOI: 10.1007/s10584-011-0208-4

5. Chang, C.C. (2002). The Potential Impact of Climate Change on Taiwan's Agriculture, Agricultural Economics, 27, 51-64. DOI: 10.1111/j.15740862.2002.tb00104.x

6. Chen, C., McCarl, B.A., and Schimmelpfenning, D.E. (2004). Yield Variability as Influenced by Climate: A Statistical Investigation, Climatic Change, 66, 239261. DOI: 10.1023/b:clim.0000043159.33816.e5

7. Cooley, T.F and Leroy, S.F. (1985). A Theoretical Macroeconometrics: A Critique, Journal of Monetary Economics, 16, 283-308. DOI: 10.1016/03043932(85)90038-8

8. Deressa, T.T., and Hassan, R.M. (2009). Economic Impact of Climate Change on Crop Production in Ethiopia: Evidence from Cross-Section Measures, Journal of African Economics, 18, 529-554. DOI: 10.1093/jae/ejp002

9. Directorate of Rice Development (2002). Rice in India: A Status Paper, Directorate of Rice Development, Patna.

10. Gbetibouo, G.A., Hassan, R.M. (2005). Measuring the Economic Impact of climate Change on Major South African Crops: A Ricardian Approach, Global and Planetary Change, 47, 143-152. DOI: 10.1016/j.gloplacha.2004.10.009

11. Ghatak, A. (1998). Vector Autoregression Modelling and Forecasting Growth of South Korea, Journal of Applied Statistics, 25(5), 579-592. DOI: $10.1080 / 02664769822837$ 
12. Granger, C.W.J. (1969). Investigating Causal Relations by Econometric Models and Cross Spectral Methods, Econometrica, 37, 424-438. DOI: $10.2307 / 1912791$

13. Gujarati, D. N., Porter, D.C., and Gunasekar, S. (2009). Basic Econometrics (Fifth Edition). New Delhi: Tata McGraw-Hill Education Private Limited.

14. Haim, D., Shechter, M., Berliner, P. (2008). Assessing the Impact of Climate Change on Representative Field Crops in Israel Agriculture: A Case Study of Wheat and Cotton, Climatic Change, 86, 425-440. DOI: 10.1007/s10584-0079304-x

15. IPCC (2007): Impacts, Adaptation and Vulnerability: contribution of Working Group II to the Fourth Assessment Report of the Intergovernmental Panel on Climate Change, Cambridge University Press, Cambridge, UK.

16. Isik, M., and Devadoss, S. (2006). An Analysis of the Impact of the Climate Change on Crop Yields and Yield Variability, Applied Economics, 38, 835-844. DOI: $10.1080 / 00036840500193682$

17. Joshi, N.P., Maharjan, K.L., and Luni, P. (2011). Effect of climate Variables on Yield of Major Food-Crops in Nepal, Journal of Contemporary India Studies: Space and Society, 1, 19-26.

18. Kabubo-Mariara, J.K., Karanja, F.K. (2007). The Economic Impact of Climate Change on Kenyan Crop Agriculture: A Ricardian Approach, Global and Planetary Change, 57, 319-330. DOI: 10.1016/j.gloplacha.2007.01.002

19. Krishna Kumar, K., Rupa Kumar, K., Ashrit, R.G., Deshpande, N.R., and Hansen, J.W. (2004). Climate Impacts on Indian Agriculture, International Journal of Climatology, 24, 1375-1393. DOI: 10.1002/joc.1081

20. Kurukulasuriya, P., Ajwad, M.I. (2007). Application of the Ricardian Technique to estimate the impact of Climate Change on Small Holder Farming in Sri Lanka, Climatic Change, 81, 39-59. DOI: 10.1007/s10584-005-9021-2

21. Lal, M., Singh, K.K., Rathore, L.S., Srinivasan, G., and Saseendran, S.A. (1998). Vulnerability of Rice and Wheat Yields in NW India to Future Changes in Climate, Agricultural and Forest Meteorology, 89, 101-114. DOI: 10.1016/s0168-1923(97)00064-6

22. Lansigan, F.P., de los Santos, W.L., Coladilla, J.O. (2000). Agronomic Impacts of Climate Variability on Rice Production in the Philippines. Agriculture, Ecosystems and Environment, 82, 129-137. DOI: 10.1016/s0167$8809(00) 00222-\mathrm{x}$ 
23. Lobell, D.B., and Field, C.B. (2007). Global Scale Climate-Crop Yield Relationships and the Impacts of Recent Warming, Environmental Research Letters, 2, 1-7. DOI: 10.1088/1748-9326/2/1/014002

24. Moula, E.L. (2009). An Empirical Assessment of the Impact of Climate Change on Smallholder Agriculture in Cameroon, Global Planetary Change, 67, 205208. DOI: 10.1016/j.gloplacha.2009.02.006

25. National Communication Project (2004). India's Initial National Communication to the United Nations Framework Convention on Climate Change. National Communication Project, Ministry of Environment and Forests, Govt. of India.

26. Ozkan, B., and Akcaoz, H. (2002). Impacts of Climate Factors on Yields for Selected Crops in Southern Turkey, Mitigation and Adaptation Strategies for Global Change, 7, 367-380.

27. Peng, S.B., Huang, J.L., Sheehy, J.E., Laza, R.C., Visperas, R.M., Zhong, X.H., Centeno, G.S., Khush, G.S. and Cassman, K.G. (2004). Rice Yields Decline with Higher Night Temperature from Global Warming. Proceedings of the National Academy of Sciences. USA, 101, 9971-9975. DOI: 10.1073/pnas.0403720101

28. Sanghi, A., and Mendelsohn, R. (2008). The Impact of Global Warming on Farmers in Brazil and India. Global Environmental Change, 18, 655-665. DOI: 10.1016/j.gloenvcha.2008.06.008

29. Sarker, A.R., Alam, K., and Gow, J. (2012). Exploring the Relationship between Climate Change and Rice Yield in Bangladesh: An Analysis of Time Series Data, Agricultural Systems, 112, 11-16. DOI: 10.1016/j.agsy.2012.06.004

30. Saseendran, S.A., Singh, K.K., Rathore, L. S., Singh, S.V., and Sinha, S. K. (2000). Effects of Climate Change on Rice Production in the Tropical Humid Climate of Kerala, India, Climatic Change, 44, 495-514. DOI: 10.1023/A:1005542414134

31. Sims, C.A. (1980). Macroeconomics and Reality, Econometrica, 48, 1-48. DOI: $10.2307 / 1912017$

32. Sinha, A.K., and Swaminathan, M.S. (1991). Long-Term Climate Variability and Changes, Journal of Indian Geographical Union, 7(3), 125-134.

33. Todd, R.M. (1984). Improving Economic Forecasting with Bayesian Vector Autoregression, Federal Reserve Bank of Minneapolis Quarterly Review, 1829. 
34. Wang, J., Mendelshon, R., Dinar, A., Huang, J., Rozelle, S., and Zhang, L. (2009). The Impact of Climate Change on China's Agriculture, Agricultural Economics, 40, 323-337. DOI: 10.1111/j.1574-0862.2009.00379.x 